\title{
風工学の勉強雑感
}

\section{Work at Wind Engineering}

\author{
理事・運営学術委員長 田村 幸雄* \\ Yukio TAMURA
}

日本風工学会の前身の日本風工学研究会が発足した のは昭和 51 年 (1976 年) である。当時は, Civil Engineering の用途に供する境界層風洞は殆どない状 況であった。今や国内には 100 以上の風洞施設を有す るようになった。小生の所属する東京工芸大学でも， 大小 7 つ風洞があり, そのうち 4 つが境界層風洞で ある。海外に較べると圧倒的に多い。本会が正会員数 500 を数えることを考えれば，施設にしても人材にし ても，日本の風工学は「量的」には世界一と言える。 国際会議などでの発表件数も, 多くの場合, 主催国の 次に位置する。量は良いとして，質はどうであろうか。 それらの豊富な施設や組織を充分に使いこなし，充分 に高品質の情報発信を行っているだろうか。以下は自 戒である。

CFD をやられている方など, 世界的に冠たるグルー プや分野もあるが，必ずしもすべてがそういう訳でも ない。風洞やフィールドでの実験的・実測的研究はか なりのものが行われている。しかし，データ整理や解 析手法, 理論的研究においては, 新規性のあるものは あまり見られない。Journal of Wind Engineering and Industrial Aerodynamics (JWEIA), Journal of Fluid and Structures (JFS)，あるいは Wind \& Structures (W\&S) な どで, 海外の研究者の論文を見ていただくと分かると 思うが，彼らは比較的新しいことをよく勉強し，研究 に採り入れている。同じアジアの香港のグループなど にも, 常に, 新しく効率的な解析手法やツールの導入 の努力が見られる。

昨年 12 月の第 17 回風工学シンポジウム論文集の引
用文献を当たってみると, 国内文献 80\%（約 550）に 対して海外文献 $20 \%$ （約 140）であった。研究は，そ れぞれのグループで継続性を持っているので, ある部 分致し方ない面もあるが, 海外文献の引用はかなり少 ない。国際会議や国際的なジャーナルでの発表論文数 の割合は，とてもこの様な比率ではない。見ていない， 当たっていないと云うことではなかろうか。これだけ 国際化し，情報交流が容易になり，盛んになった現在 でも，それらの情報に目を向け，真剣に勉強しなけれ ば，実は何も吸収できない。日本は，比較的自国内に おける風工学研究が充実しているので, これで事足れ りとしておられるのかもしれないが, 所詮, 井の中の 蛙である。JWEIA, JFS ほかの海外の情報に目を向けた とき, “新規性”という意味では，圧倒的に情報量が異 なることに気づく。

ルーティン化した日常業務としての実験や研究をこ なすだけであれば，そこで要求される知識や技術に， 不自由は感じないのかも知れない。しかし, 風工学の 世界も常に進歩しており，日々努力をしていないと， あっという間に化石のような存在となってしまう。本 人が気がつかないうちにそれが起こり, 気がつかない まま事態が進行し，それでもそのまま通用してしまっ ているだけなのである。大変怖い。

このような恐怖から逃れるため, 小生も, 最低限の 勉強時間は設けることにしている。十数年続いている 土曜日の勉強会もその一つで, 夕方まで最新の文献を 読み，回転の鈍い頭をギリギリ使って，若い人と大い に議論するのである。企業の研究者の方々も，かなり 
参加して下さっており，難解な文献や書籍など，とに かく新しいことを色々勉強する。有効な勉強ができて いるかどうか自信はないが，永く続けると良いことも あり，新しい情報を得るというだけでなく，何年かに 一度は, 自分にとって非常に新鮮な数学的ツールや解 析手法に出くわす。理解するのに時間が掛かるほど, 解きほぐしていくプロセスが面白く，2 次的な収權も 多い。応用の奥深さもある。この辺は，大学に職を置 く者のみの醍醐味と思れるであろうが, 決してそうで はない。研究会には企業の方も参加されており, 強制 されずに永年続けて集まって来られるところを見ると， 同じ喜びを満喫されているのだと思う。

数学的ツールの威力は, 単純な数学的操作を講じる だけで，人間の思考能力だけではとうてい到達できな い解の世界に自動的に導いてくれるところにある。し かし，思考を駆使した議論は，さらに重要である。議 論をしていくうちに, 自分の考えや理解も明確なもの となり, 思い違いや, 数式の持つ意味の別の側面に気 がついたりする。紆余曲折はあっても, 諦めさえしな ければいずれ正解に近づく。何人かでそりに乗り，ガ ツガツ側壁にぶつかりながらもゴールに近づくボブス レーのようなものであろうか。他人に説明するための 解説を考えることも，本質を正しくとらえ，奥行きの ある理解をする上で大いに役立つ。以前, Proper Orthogonal Decomposition (POD) の解説を, 本誌に書 くように現会長の松本勝先生から仰せつかった。単な る数学的記述や解説ではなく, その本質的な意味を分 かり易く解きほぐせということであった。かなり多く の文献を当たったが, 実感の沸く説明は全く見つから なかった。苦労しているうちに, 多点の観測記録波形 を多次元空間の 1 点の軌跡で表現すると, 多自由度の ランダムな現象を分かり易く説明できることに気がつ いた。本当に悪戦苦闘の結果である。これに「状態軌 跡」(state locus) と名前を付けた。それ以来, この現象 観測の仕方が他の研究でも大いに役立っている。松本 先生には，大変良い機会を与えて下さったと感謝して いる。

どんな現象や事柄でも，その対象を手のひらの上に載 せ, 矯めつ眇めつ, あらゆる角度から見られるような状 況になって初めて,そのものを理解したとの害感がわく。 事実や真実を伝えるためには, “徹底した”理解と実感 がこちら側になければならない。これは大変重要で, 実 験や研究も, 徹底した理解ができたと思えるところまで 持っていかないと, 所期の目的を達成できない。途中で
思考や議論をやめてしまうと,それを実感する権利も機 会も失ってしまうのである。

ずいぶん昔, 学位論文の対象として渦励振の数学モ デルを研究していた。考えていたモデルは, Birkhoff の振動子モデルに, 長さの変化を取り入れて非線形性 を導入しょうというものである。Di Silvio の論文で見 た流れのパターンがヒントとなった。渦発生現象や渦 励振現象の枝葉末節を取り除いて，本質を失わない程 度に単純化した姿を見た気がして, 大いに“現象の理 解”を意識したものである。円柱の渦励振のロックイ ン現象など, 非線形性の強い現象も含めて実験値をか なり良くシミュレートでき, 当初考えていた目標は達 成できた ... と思っている。しかし, 最終形に至るま でには随分と紆余曲折があり，時間がかかった。パン チカードを読ませたら，翌日まで待たないと結果が出 ないという当時のコンピュータ環境の所為ではない。 ミスを修正して，これで良しと思って翌日結果を取り に行ったら，全く失敗に終わっているということを， 何十回, 何百回と繰り返したからである。理論式導入 プロセスでの久陷, プログラムのバグ, 解を求めてい くプロセスでの技術的誤り等々, 原因は広範で膨大で あった。おまけに, 一つ一つの誤りは, 論理的構成や 方程式の向こう側に, 極めて巧妙に隠れており, 容易 に発見できない。それを苦労して見つけるたびに，大 発見した気分になり，とうとうこれで旨く行ったと“確 信”する。どう見ても他に欠陥はなく, 完璧だとしか 思えない。しかし，翌日は，ひどく打ちのめされる。 その繰り返しであった。

数学的, 力学的な考察をあらん限りに行い, どう見 ても非の打ち所がないと思えるものでも，間違ってい るのである。そこで学んだことは, あらゆる角度から 検証して,これ以上完壁なものはないと思えるもので も, 間違いの可能性が常にあるのだということであり， 人間の直感や感覚ほど怪しげなものはないということ であった（本当は，個人的な能力の問題であったのだ とは思うが)。

一方では，モノの本質を失わず，かつマクロに現象 を捉える直感的な発想が数学モデルの起点となってい るというのも事実であって, 人間の感覚の重要性を教 えるものでもあった。

何とも奇妙な体験を積んだものであるが，いまだに その印象は払拭できず, 確信もなく両者を摇れ動いて いる。実に頼りない。 